\title{
Da minha janela vejo o mundo passar: Lima Barreto, o centro e os subúrbios ${ }^{1}$
}

\author{
LILIA MORITZ SCHWARCZ ${ }^{I}$
}

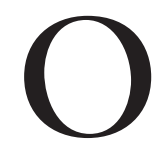

S subúrbios cariocas e a linha da Estrada de Ferro Central do Brasil foram motes prediletos na obra de Lima Barreto. Por vezes eles surgiam como coadjuvantes; por vezes, viravam atores principais. No "centro" ele trabalhava como amanuense, encontrava sua turma de farras, percorria os bares e as redações de jornal (cf. Resende, 2016). Era também por lá que perambulava e colhia material, andava como flâneur, ou simplesmente acompanhava o ritmo acelerado da cidade. Era, porém, no percurso que percorria todos os dias - do subúrbio de Todos os Santos, na Rua Boa Vista, até a Secretaria da Guerra, que ficava na Praça da Aclamação (atual Praça da República), e vice-versa -, que o escritor encontrava tempo para observar não só passageiros, como as arquiteturas das várias estações, os vizinhos, os “aristocratas do local”, os funcionários públicos como ele, os estudantes, os humilhados, os operários, as moças. O trajeto do trem era pretexto, ainda, para marcar diferenças sociais que delimitavam classe, raça, gênero e região, singularidades que ficavam ainda mais claras quando comparadas com a população da capital. O importante é que no conjunto de sua obra o escritor vai elaborando essa geografia íntima, a partir do percurso que empreendia entre os subúrbios e o centro do Rio, e o oposto também.

A literatura de Lima pode ser considerada, portanto, e a partir de 1903, quando aceita o trabalho na Secretaria da Guerra, como uma "literatura em trânsito", marcada por um discurso ambivalente. Em alguns escritos sua vizinhança representa a pureza não conspurcada pela "civilização artificial do Rio"; em outros, os subúrbios não passam de locais com hábitos atrasados e pouco preparados para uma nova modernidade. E a mesma ambivalência é demonstrada nos escritos sobre o "centro"; considerado por Lima como um local de práticas estrangeiradas e importadas, é também o espaço para seu projeto de sucesso na literatura.

A linha do trem é, assim, e ao mesmo tempo, um traçado geográfico, simbólico e identitário que demarca projetos de inclusão e de exclusão social. De um lado, trata-se de uma retórica do subúrbio, uma vez que o escritor faz questão de nomear o lugar onde mora, e de utilizá-lo como diferencial da sua literatura. De outro, muitas vezes, usa uma terceira pessoa magnânima, como se não fizesse parte daquele local. O "subúrbio tem disso", escreve ele em Clara dos Anjos (Barreto, 2012). 
Um dos grandes personagens de Machado de Assis, Dom Casmurro, já declarara que, sentindo o peso dos anos, viúvo, pretendia escrever algo novo e útil para as gerações que iam surgindo: "uma História dos Subúrbios". O projeto acabaria engavetado por Casmurro, mas o mais importante é o que o plano antecipa: um processo de reconfiguração urbana do Rio que a trama do romance bem simboliza (Machado de Assis, 2016, p.392). Com efeito, no período de 1890 a 1906 houve um aumento populacional considerável nas freguesias suburbanas mais próximas ao centro, especialmente Engenho Novo (que cresceu $126 \%$, passando de uma população residente de 27.873 em 1890 para 62.898 em 1906) e Inhaúma (com crescimento de $293 \%$, devido ao aumento da população residente para $68.557 \mathrm{em} 1906$ contra 17.448 de 1890). Se por um lado cresce a população dos subúrbios em decorrência do deslocamento exigido pelas obras de modernização da região central da cidade, cresce também a ocupação da zona sul como consequência da melhoria dos bondes, que passavam a ser elétricos (Abreu, 1987, p.64-5). De acordo com o recenseamento realizado em 20 de setembro de 1906, a população do Rio de Janeiro alcançou o total de 811.443 habitantes, sendo 625.756 domiciliados na zona urbana e 185.687 , na suburbana. ${ }^{2}$

Já Lima guardava uma postura, digamos assim, mais "contaminada". Eles e seu autor faziam parte fundamental dos subúrbios, mas sempre de forma ambígua; eram uma espécie de "ser $e$ não ser". O conceito suburbia tem origem latina, e chegou a aparecer nos círculos cultos do Renascimento. No entanto, foi sobretudo durante a reforma urbana empreendida por Napoleão III que ele se tornou recorrente, designando as regiões não abarcadas pelo centro da cidade, mas a ele adjacentes. Na Inglaterra ficaria vinculado aos projetos de ocupação dos bosques ajardinados ao leste de Londres. $\mathrm{Na}$ época da Revolução Industrial seria destinado a agentes sociais que pretendiam viver longe da poluição da capital, mas com fácil acesso a ela. Na França estaria relacionado a um novo grupo social que conquistava o espaço urbano, em termos de consumo, ostentação e lazer. Não por acaso, Balzac, autor de predileção de Lima, dedicou-se a escrever crônicas sobre esses novos grupos dos subúrbios, desfazendo, em A comédia bumana, de seus valores argentários, exibição e delírio de poder.

Com a chegada da estrada de ferro e o incremento das atividades urbanas, novas áreas foram sendo dotadas de infraestrutura, mesmo que um pouco afastadas do centro. Elas eram vizinhas das grandes capitais, possuíam uma paisagem mais ajardinada, mas distante da movimentação e dos ruídos das metrópoles. Esse era pelo menos o sentido europeu e norte-americano do conceito. Se a urbe representava a vida selvagem; o subúrbio carregava a sofisticação e o afastamento da desordem da cidade. "A cidade era a senzala - afirmava Nicolau Sevcenko - o subúrbio a casa-grande" .

O escritor argentino Jorge Luis Borges também destacou o novo lugar ocupado pelos subúrbios de Buenos Aires como um espaço imaginário que se 
contrapunha à cidade moderna (Sarlo, 2008). O mesmo faria Walter Benjamin (1997) que definiu esses locais como "o estado de sítio das cidades, o espaço de batalha onde se deflagra, ininterruptamente, o combate decisivo entre a cidade e o campo, o moderno e a tradição".

O sentido dado aos subúrbios cariocas de finais do século XIX e inícios do XX seria semelhante, mas também particular. Nesse momento, vários serviços que visavam a melhoria da malha urbana redefiniriam os espaços sociais. Além do mais, com o advento do regime republicano um acelerado processo de substituição de elites pode ser verificado. Essa foi a nossa "Comédia Humana", sendo que dentre as várias modificações que a nova situação financeira preparava, a atividade mais rentosa passou a ser a especulação financeira, e, acima de tudo, a especulação imobiliária que expulsou os trabalhadores, agora livres, do centro da cidade.

Machado publicou Dom Casmurro em 1899, durante o governo de Campos Salles. Não por acaso, Bentinho buscou inspiração, também, nas figuras de César, Augusto e Nero, ditadores militares que se beneficiaram do colapso da república romana, estabelecendo o império. O que conta a história é que as prodigiosas riquezas cartaginesas levaram consigo as últimas virtudes e instituições republicanas. Já o personagem Bentinho parece acompanhar a reconfiguração do espaço urbano, com suas mudanças de residência seguindo a rota de expansão dos novos subúrbios refinados. Há, entretanto, uma diferença fundamental: a nova casa do personagem de Machado é uma réplica exata da sua primeira residência, na rua Matacavalos. Isto é, por mais que se altere a área da especulação, ela mantém o padrão estamental e o estilo senhorial da sua origem.

Também não é coincidência o personagem-chave, Escobar, ter origem subalterna e ser definido como calculista, interesseiro e negocista. Nesse sentido, "História dos Subúrbios" teria sido um notável livro da lavra de "Dom Casmurro". Machado de Assis extraía o termo para se referir aos bairros da Gamboa, de Copacabana ou da Tijuca, e para dar conta de uma espécie de topografia do arrabalde, sempre indecisa entre as primeiras casas da área urbana e as derradeiras construções da zona rural, entre as qualidades perdidas de uma cultura que vai se apagando e o lado corrosivo, inacabado, violento e trágico da ruína que se constroi. Essa era a realidade de inícios do XX: nos lugares de subúrbio a cidade moderna está sempre por fazer-se e sob os escombros.

Os subúrbios também variaram, e muito, na literatura de Lima. Por vezes apareciam como locais de muita penúria e falta de estrutura; por vezes espaços povoados por uma classe média baixa ou até mesmo por uma elite que queria morar perto do centro sem sofrer com a movimentação do dia a dia. O certo que os subúrbios eram "muitos"; diferiam em estrutura e na paisagem humana. Se existiam algumas estações mais pobres e sem maiores equipamentos, havia outras habitadas por uma classe média composta por funcionários públicos, e que procuravam encontrar um ar saudável e preços de aluguel módicos. Literatura 
nem sempre é boa etnografia - no sentido de ser fiel ao contexto que procura descrever. Na verdade, ela muitas vezes trapaceia com a realidade que diz lidar; faz da memória pretexto para o enredo que se quer desenvolver. Também para Lima os subúrbios eram uma estratégia discursiva; uma maneira de construir um projeto literário alternativo. Não tanto o subúrbio elegante, mas aquele dos trabalhadores da Central, dos metidos a aristocracia, da gente endomingada e de costumes simples. Não por coincidência, os melhores personagens de Lima Barreto serão ambientados fora do centro, com os subúrbios virando seu melhor cenário e definição.

\section{No trem da Central do Brasil: ida e volta}

Com a reforma urbana, a região central da capital carioca passou a representar "o grau zero" da cidade, enquanto novas classificações urbanas foram sendo criadas, com o objetivo de definir os espaços mais afastados da cidade, mas ainda assim integrados a ela. "Arrabaldes" eram as regiões que se localizavam para além do centro, e "subúrbios" as que ficavam fora da cidade. Clássicos arrabaldes eram o início da zona sul como Glória, Flamengo, Botafogo, assim como (na zona norte) Catumbi, Rio Comprido e Tijuca.

Havia bolsões de miséria em todos os locais, assim como áreas mais abonadas misturavam-se a regiões onde habitavam trabalhadores sem tantos recursos. Porém, no imaginário social foi se construindo a noção de que a provisoriedade estaria concentrada mais nos subúrbios; o que era e não era verdade. Como vimos, as duas primeiras décadas do século XX foram marcadas por extensas reformas urbanas no centro, e levaram a um grande deslocamento populacional em direção aos subúrbios. E se boa parte desse movimento era composto por uma população sem grandes recursos, um contingente significativo era feito de funcionários públicos. Francisco Pereira Passos (1836-1913) entre os anos de 1903 e 1906 atuaria como prefeito no Rio e seria o principal executor de um plano urbanístico de grandes dimensões, e que acabaria por mudar a paisagem do centro da cidade, mas seus entornos também. Se é verdade que certas elites se transferiram para os arredores próximos; já os subúrbios, nomeadamente os mais afastados, foram dominados por um contingente formado de pobres, e sobretudo negros, muitos deles recém-saídos do sistema escravista, trabalhadores nacionais e imigrantes, funcionários públicos de médio e baixo escalões. $\mathrm{O}$ crescimento das favelas também convive e faz parte da expansão dos subúrbios cariocas. Já no final do século XIX registros mostram sua presença não só na área central do Rio de Janeiro - os morros da Favela e de Santo Antônio -, como nas faixas suburbanas da cidade (Silva, 2010, p.165).

No Rio de Janeiro das últimas décadas do XIX, o termo "subúrbio" muitas vezes usado no plural, por conta da grande diversidade interna - passou a denominar e classificar áreas fora do centro, de uma forma geral, e descrevia a região residencial e industrial constituída entre a Serra do Engenho Novo, o Morro do Telégrafo (na Mangueira) e o Morro do Retiro (em Realengo). Esse 
território longilíneo seria assim demarcado não só por conta de sua geografia física, como por causa da linha férrea que corria do centro em direção ao interior. Esse é o motivo que explica o formato dos subúrbios cariocas. Ao invés de assemelharem-se ao desenho de outras periferias urbanas, que normalmente espalham-se contornando os núcleos centrais das grandes cidades, no caso do Rio os subúrbios distribuem-se numa faixa estreita e contínua que caminha para o lado oeste, recebendo designações sucessivas.

Atraídas pelo baixo valor dos lotes de terreno, e pelo transporte ferroviário mais fácil e barato, uma população numerosa foi ocupando a região. Criaram-se também hierarquias internas, com alguns bairros considerados menos providos de infraestrutura - como Cascadura, por exemplo - e outros tidos como até elegantes. Esse seria o caso de Boca do Mato - conhecido por conta de seu clima serrano como "Suíça suburbana" ou "Europa dos pobres" -; Jacarepaguá, Tijuca, Gamboa, e em certo sentido o amplo distrito do Méier. Os bairros menos equipados são, não por coincidência, os mais distantes do centro e povoados por uma população pobre e imigrante, que sai do Rio com a Reforma Passos ou mesmo com o final da escravidão. Já as vizinhanças mais "aristocráticas" seriam habitadas pelas elites que teriam optado por viver em chácaras ajardinadas -, assim como um vasto funcionalismo público, resultado da grande oferta de empregos administrativos na capital.

No início da década de 1890, a divisão administrativa da cidade deixou de ser feita em "freguesias". Adotou-se, então, a nova categoria de "distritos", que eram por sua vez subdivididos entre "urbanos" e "suburbanos". Sabemos que novas classificações não são criadas e consolidadas se não existirem necessidades reais para sua implementação. Nesse caso, os termos expressavam a crescente urbanização e expansão espacial do Rio, assim como correspondiam a uma separação entre as regiões consideradas mais urbanas e outras mais rurais. Até então a região do Méier (que incluía, nesse contexto, os bairros do Méier, Todos os Santos, Boca do Mato, Água Santa, Lins de Vasconcelos, Cachambi e Engenho de Dentro) fazia parte da freguesia do Engenho Novo. O distrito do Méier era dos mais próximos à região central, contava com avanços urbanos em sua estrutura e por isso garantiu para si o título de "capital do subúrbio".

No recenseamento de 1906, a população do Rio foi dividida entre moradores da "Cidade" (628.041) e dos "Subúrbios" (183.402). Já a população total do distrito do Méier cresceu de maneira acelerada entre 1906 e 1920: passou de 34.476 para 57.252 habitantes, variando de $4,28 \%$ para $4,99 \%$ em relação à população total da cidade. ${ }^{4} \mathrm{O}$ distrito espelhava, pois, um pouco o perfil "socioeconômico" dominante na região e nos bairros mais próximos. Na composição populacional, dividida a partir dos ramos profissionais, destaca-se, ainda, o grande número de funcionários públicos. No ano de 1906, por exemplo, época em que Lima por lá morava, o Méier já era a região com maior número absoluto de servidores do Estado. 
Além dos funcionários públicos e dos operários, no registro da população local é relativamente elevado o número de empregados atuando no comércio. Tal crescimento, aliás, já começava a fazer do bairro do Méier o grande centro comercial dos subúrbios. Na Tabela l é possível visualizar a composição socioeconômica do bairro por meio de dados retirados dos recenseamentos de 1906 (da cidade do Rio de Janeiro) e de 1920 (nacional). Segundo o recenseamento, existiram quatro categorias dominantes da região: 316 profissionais em "produção de matéria-prima"; 6.935 profissionais em "transformação e emprego da matéria-prima"; 2.148 profissionais em "administrações públicas e profissões liberais"; e 25.052 classificados em "outras".

Dos 2.148 profissionais da categoria "administrações públicas e profissões liberais", há um total de 1.218 que ocupam a subcategoria "funcionalismo".

O censo de 1906 também pesquisou o nível de instrução dos moradores de cada distrito. No Méier, a população era dividida entre 19.110 que "sabem ler ou escrever"; 14.180 que "não sabem ler ou escrever", e 1.186 cujo grau de instrução não foi informado. A proporção do bairro $(55,4 \%$ de alfabetizados para $41,1 \%$ de analfabetos) era próxima da média geral do Distrito Federal - que chegava a $51,9 \%$ alfabetizados -, ainda que ambas fossem bastante discrepantes da média nacional que atingia o impressionante número de 74,6\% de iletrados. Esses dados destacam o argumento que estamos aqui perseguindo: a composição profissional dos moradores dos subúrbios, ao menos aqueles mais próximos da capital era bastante elevada para os padrões nacionais.

Quanto à nacionalidade dos moradores do Méier, o censo de 1906 dividia-os em:

Tabela 1 - Censo de 1906 . Nacionalidade dos moradores do Méier

\begin{tabular}{llll}
\hline Nacionalidade & Homens & Mulheres & Total \\
Brasileiros & 15.885 & 13.744 & 29.629 \\
Portugueses & 2.660 & 783 & 3.443 \\
Italianos & 262 & 117 & 379 \\
Espanhóis & 180 & 95 & 275 \\
Turcos/Árabes & 46 & 19 & 65 \\
Alemães & 28 & 30 & 58 \\
\hline
\end{tabular}

Tratava-se, pois, de um Distrito basicamente composto por uma população de origem brasileira, marcado por uma classe média baixa que ocupava os fartos cargos do funcionalismo público oferecidos para aqueles que residissem na capital ou em suas cercanias. Por sinal, o número de indústrias instaladas no distrito do Méier em 1906 não era grande: 18 em 1906, e 39 em 1920. Enfim, os subúrbios mais próximos do centro, como aquele de Todos os Santos onde Lima morava, não eram exatamente "operários"; eram vizinhanças habitadas pelo imenso exército de funcionários públicos, como ele, e outrora seu pai, a serviço do Estado. 


\section{A Estrada de Ferro Central do Brasil (E.F.C.B.): uma linha quase simbólica ${ }^{5}$}

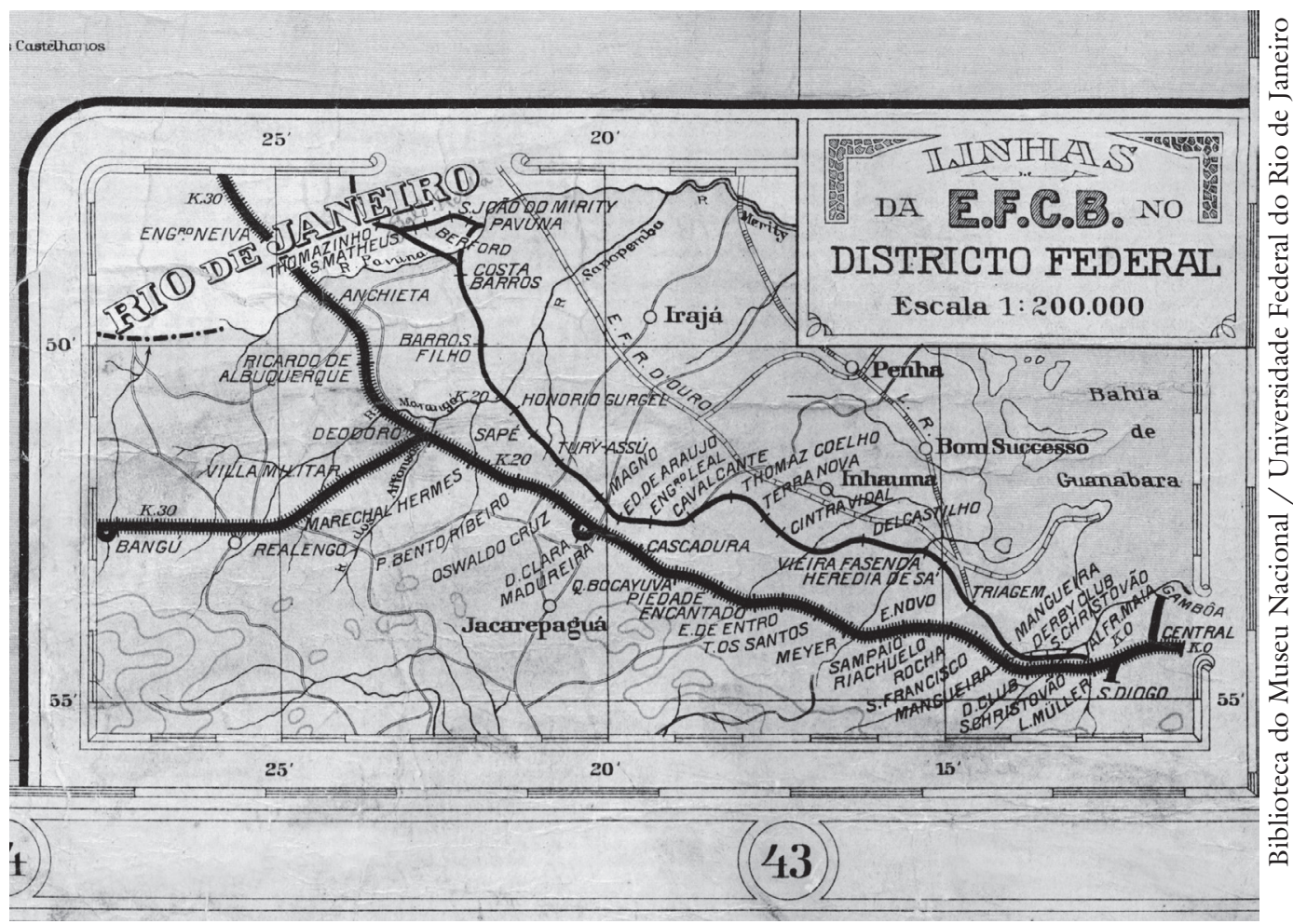

Figura 1 - Detalhe do mapa "Carta das linhas da Estrada de Ferro Central do Brasil". São Paulo: Ypiranga, 1919.

Lima Barreto mostra como as diferentes estações de trem davam ensejo à constituição de identidades próprias a cada bairro: as definições internas mas também partilhadas pelos vizinhos. Era a existência ou não de tetos nas plataformas; a parada mais ou menos longa; o fato de o local ser cortado pela linha do trem ou contar com plataformas seguras que conferiam "personalidade" a cada estação. Mas era sobretudo sua disposição em relação ao marco zero - que definia a Central - que dava maior ou menor importância ao local.

Essa lógica era também criada pela própria história das estações. Quando da inauguração da Estrada de Ferro Dom Pedro II, em 29 de março de 1858, os subúrbios contavam com as estações de Engenho Novo, Cascadura, Maxambomba (Nova Iguaçu) e Queimados. No ano seguinte, a linha seria ampliada com a inauguração das estações de São Cristóvão, Sapopemba (Deodoro) e Belém (Japeri). De modo geral, as estações do subúrbio foram surgindo ao longo das últimas décadas do século XIX e início do XX, conforme o adensamento da população e a constituição dos bairros, que vão se formando no lugar de antigas fazendas, sítios e terrenos privados. Para se ter uma ideia, até se chegar a Engenho de Dentro - estação próxima daquela em que Lima vivia, em Todos os 
Santos, era necessário passar por 11 estações, cumprindo-se os primeiros 11,3 $\mathrm{km}$ da linha (Vasconcelos, 1947).

Foi no ano de 1861 que a então chamada Estrada de Ferro Dom Pedro II passou a contar com um serviço regular de trens de passageiros para os subúrbios do Rio, ao longo da chamada "Linha do Centro". Já as estações dos subúrbios eram servidas por dois tipos diferentes de trens: os de "pequeno percurso" (que ultrapassavam a zona dos subúrbios chegando até estações mais distantes) e os "trens de subúrbios". Enquanto os primeiros paravam apenas nas estações de Cascadura e de Engenho de Dentro; já os segundos faziam pausas em todas as estações, tornando o tempo de viagem muito mais longo.

A parada do trem vai assim diferenciando os subúrbios "melhores" daqueles considerados "piores". Os "melhores" eram aqueles mais bem fornidos, onde os trens "diretos" paravam sempre. Já os "piores" seriam os que o trem não fazia escala - só os locais e de subúrbio -, em que motorista detinha-se pouco, os passageiros entravam e saiam rapidinho, e não eram muitos. Por exemplo, em 1910, os trens de subúrbios chegavam a levar 40 minutos entre Central e Cascadura, enquanto os trens "diretos" gastavam cerca de 20.

Mas existiam ainda outras hierarquias internas. Até final do XIX, os carros de passageiros eram divididos em três classes, sendo utilizadas, posteriormente, apenas a divisão entre a $1^{a}$ e a $2^{a}$ classes. Em 1907, o custo da passagem de trem para passageiros no percurso entre Central e Deodoro ou Dona Clara (estação conexa a Madureira) era bastante diferenciado: nos trens de "pequeno percurso" pagavam-se $\$ 500$ réis na $1^{\text {a }}$ classe e $\$ 300$ réis na $2^{a}$. Nos "trens de subúrbios" a primeira classe custava $\$ 300$ e a segunda, apenas $\$ 200$. A diferença no preço da passagem fazia que a maior parte dos trabalhadores circulasse nos "trens de subúrbio", cuja segunda classe ganhava o nome de "trem dos operários". A composição social dos passageiros também explica o fato de o movimento ser bem maior nos horários da madrugada. Por volta de 1910 , entre $4 \mathrm{~h} 5 \mathrm{lmin}$ e $5 \mathrm{hl} \mathrm{lmin}$, partiam quatro trens de Cascadura para a Central, com intervalos menores que dez minutos. O inverso acontecia no final da tarde, quando 10 trens saíam da Central entre $17 \mathrm{~h}$ e $18 \mathrm{~h}$.

Se os homens faziam uso diário do vagão do trem, para chegar ao trabalho, já as donas de casa muitas vezes permaneciam em casa, construindo suas relações na vizinhança. Na foto do vagão de segunda classe, são quase que só homens trabalhadores que usam o transporte. Destaca-se também a coloração escura dos passageiros e o título popular que recebia: "trem operário".

E vale a pena observar como, nesse quesito, Lima se aproximava e se distinguia dos passageiros que tomavam o trem mais barato. "Antes", escrevia ele, só tomava os trens "da primeira"; "depois", "por prazer e opção", teria resolvido aderir aos "da segunda". Nas palavras do amanuense: "Habitualmente não viajo em segunda classe; mas tenho viajado, não só, às vezes, por necessidade, como também, em certas outras, por puro prazer. Viajo quase sempre de primeira classe e isso, desde muito tempo" (Barreto, 1921c, p.2). 


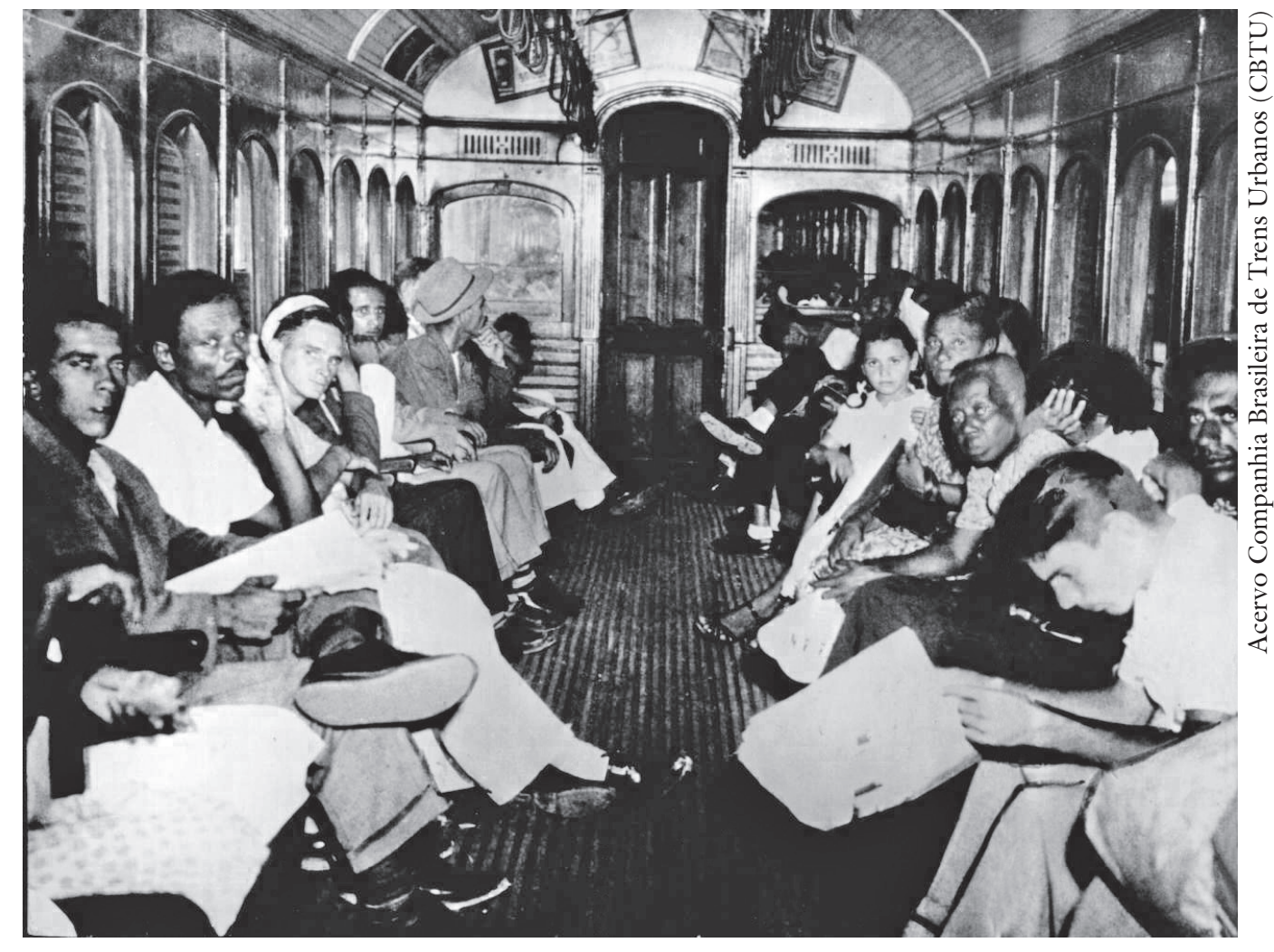

Figura 2 - Vagão $2^{\text {a }}$ classe (s.d.).

O escritor parece justificar tal escolha por conta das “observações" que realizava nos vagões; uma espécie de laboratório para sua literatura. E não deveria faltar material, uma vez que o número de passageiros crescia, assim como a distância entre as classes.

Tabela 2 - Número de passageiros transportados anualmente pela E.F.C.B. em trens dos subúrbios

\begin{tabular}{llll}
\hline Ano & $\mathbf{1}^{\text {a }}$ classe & $\mathbf{2}^{\text {a }}$ classe & Total \\
1890 & 1.612 .764 & 3.961 .636 & 5.576 .290 \\
1895 & 3.975 .578 & 7.234 .178 & 11.211 .651 \\
1900 & 3.677 .563 & 8.803 .263 & 12.482 .726 \\
1906 & 6.122 .726 & 13.116 .510 & 19.241 .142 \\
\hline
\end{tabular}

Fonte: Figueira (1908).

Todos os trens, sem exceção, partiam da Estação Central considerada a mais elegante e bem equipada. Talvez por conta de tanta projeção a Central foi ganhando vários nomes ao longo da sua história. No Império era chamada de estação do "Campo" ou da "Corte", para se nomeada de "Central" com o advento da República. ${ }^{6}$ A mudança constante é prova dos significados simbólicos a 
ela conferidos. No fundo ela era mesmo "central": representava o encontro e o desencontro entre o centro do Rio e seus subúrbios, que forneciam, a cada dia, os trabalhadores necessários para que a capital cumprisse o papel administrativo e econômico que possuía.

Tabela 3 - Número total de viajantes por ano nos trens de subúrbios da "Linha do Centro"

Ano
1900
1905
1910
1915
1920

$N^{\circ}$ de passageiros

12.627.197

17.781 .547

23.592.123

29.138.055

38.437 .019

Fonte: "Introdução ao Relatório do anno de 1925, apresentado ao exmo. sr. dr. Francisco de Sá (ministro da Viação e Obras Públicas) pelo Engenheiro João de Carvalho Araújo". Rio de Janeiro: Pimenta de Mello \& C., 1926.

\section{Todos os Santos ou a falta deles}

A importância que as estações adquiriam para seus moradores não escapou à percepção de Lima. O escritor estabelece, inclusive, um paralelo sensível entre os trilhos de trem e a sociabilidade local:

Na vida dos subúrbios, a estação da estrada de ferro representa um grande papel: é o centro, é o eixo dessa vida. Antigamente, quando ainda não havia por aquelas bandas jardins e cinemas, era o lugar predileto para os passeios domingueiros das meninas casadouras da localidade e dos rapazes que querem casar, com vontade ou sem ela. Hoje mesmo, a gare suburbana não perdeu de todo essa feição de ponto de recreio, de encontro e conversa [...] (Barreto, 1921a, p.2)

Tudo girava em torno da "estação", que é definida por Lima como "verdadeira e caracteristicamente suburbana". Conta ele que na hora em "que descem os empregados públicos, os pequenos advogados e gente que tal”, o melhor é "ver e ouvir as palestras e as opiniões daquela gente toda, sempre a lastimar-se de Deus e dos governos". Usando de um olhar distanciado, a despeito de ser, ele mesmo, usuário do trem, o escritor os define como uma "gente em cuja mente a monotonia do ofício e as preocupações domésticas tiraram toda e qualquer manifestação de inteligência, de gosto e interesse espiritual, enfim, uma larga visão do mundo [...]". Crítico, Lima como que se ausenta do relato, e trata colegas de profissão e vizinhos de casa se fossem estranhos: "O brasileiro é vaidoso e guloso de títulos ocos e honrarias chôchas. O seu ideal é ter distinções de anéis, de veneras, de condecorações, andar cheio de dourados [...]. Quanto mais modesta for a categoria do empregado - no subúrbio pelo menos - mais enfatuado ele se mostra" (Barreto, 1921c). 
Mas o sarcasmo de Lima não se limita aos homens; também as mulheres são descritas a partir das diferenças de classe: “[ ... Fui atraído para uma menina que passava carregando uma caixa de violino, um rolo de músicas e um livro [...] Pobre Moça! Pra que? No instituto, só têm talento musical as moças ricas e bem aparentadas". O escritor também descreve como elas eram minoria naquele ambiente, e palco para todo tipo de assédio: "A essa hora, na estação, as moças e senhoras escasseiam; a hora delas é mais tarde, para depois do meio-dia. Às vezes, porém, aparece uma outra desgarrada. Quando isso se dá, todos aqueles exemplares de chefes de famílias e exatos funcionários estremecem nos seus assentos $[\ldots] "$.

A viagem de trem é assim um observatório em que Lima anota as diferenças de classe, gênero, cor e estação. Narra ele que a

[...] mania dos suburbanos é discutir o merecimento deste subúrbio em face daquele. Um morador do Riachuelo não pode admitir que se o confunda com um do Encantado e muito menos com qualquer do Engenho de Dentro. Os habitantes de Todos os Santos julgam a sua estação excelente por ser pacata e sossegada, mas os do Méier acusam os de Todos os Santos de irem para o seu bairro tirar-lhe o sossego. (Barreto, 1915)

E se isso tudo é verdade, é forçoso reconhecer que Todos os Santos, a estação que Lima frequentava, era das mais modestas; só tinha a seu favor o fato de ser uma das mais antigas. Fora inagurada nos idos de 1868 e ainda nos anos 1870 não passava de uma parada rápida. Apenas anos depois, e quando Lima não estava mais vivo para contar, é que se tornou uma estação, no sentido tradicional do termo, contando com bilheteria e alpendre. Mas antes disso, ela guardava sonolenta sua mesma estrutura inicial.

Todos os Santos era definitivamente uma estação pequena e simples, com uma cobertura de duas folhas sobre uma plataforma de $139 \mathrm{~m}^{2}$, cujo acesso era realizado diretamente pelos trilhos. $\mathrm{O}$ fato de a população ter que atravessar os trilhos a pé representava com certeza um grande risco, mas também levava a uma espécie de desclassificação dentre as estações. E esse era o caso de Todos os Santos que nasceu pequena. ${ }^{7}$

Para piorar, ela ficava espremida entre duas maiores: Méier e Engenho de Dentro. Não só o movimento nas duas paradas vizinhas era crescente, como as diversas obras para o aumento da plataforma do Méier acabaram resultando numa distância ainda menor entre as duas estações.

Aliás, a exemplo do que ocorria em outros subúrbios, o bairro onde Lima morou era também uma espécie de consequência da sua estação. Se originalmente fazia parte da Freguesia de Inhaúma, seria em 1873 associado à Freguesia do Engenho Novo. Seguindo a lógica da organização da Estrada de Ferro Central do Brasil, Todos os Santos correspondia à parada seguinte à estação do Méier. No entanto, chama atenção a inexistência de qualquer demarcação geográfica clara, especificando a fronteira entre os dois locais. Uma vez que os 
dois bairros eram basicamente contíguos, a distinção - mais simbólica do que real - tinha lá seus significados internos: enquanto o Méier representava o agito, Todos os Santos era pura calmaria.

Tabela 4 - Número total de passageiros no decênio 1886-1896

\begin{tabular}{ll}
\hline Estação & No de passageiros \\
São Francisco Xavier & 2.340 .663 \\
Engenho Novo & 3.490 .954 \\
Méier & 3.266 .585 \\
Todos-os-Santos & 2.112 .142 \\
Engenho de Dentro & 4.542 .508 \\
Cascadura & 4.058 .513 \\
\hline
\end{tabular}

Fonte: Noronha Santos (1996).

A parte mais característica de Todos os Santos (e onde Lima morou) é a região Leste. Descrições da época mencionam um bairro conhecido pela "quietude", por ser uma região basicamente residencial e pacata, ainda mais quando comparada ao Méier, cujo movimento comercial e de lazer contribuiu para a fama de "capital do subúrbio". Todos os Santos, por sua vez, e segundo Noronha Santos, um dos melhores amigos de Lima, comportava "belos prédios, de custosas construções e grandes chácaras com arvoredos frutíferas”. Além do mais, por conta do terreno montanhoso o clima era dos mais "saudáveis e recomendado por muitos médicos para doentes de moléstias pulmonares" (Santos, 1965, p.36).

E se Todos os Santos foi, ao longo das primeiras décadas do século XX, equipando-se, mesmo assim, continuava modesta. O Méier possuía, a essas alturas, mais de três cinemas e um teatro (ibidem). Todos os Santos chegou a ter duas salas para cinematógrafos na década de 1930; todas fechadas por volta do final da década de 1960. A região dos subúrbios, de uma forma geral, crescia a olhos vistos. Enquanto no recenseamento de 1890 a população da freguesia não alcançava os 28.000 habitantes; já no ano 1906 a região contava com uma população de 62.898 almas. Esse é o período de maior expansão e crescimento populacional da região; aliás, proporcional à ampliação de serviços na Capital. Já a história de Todos os Santos era, porém, bem diferente: costumes pacatos, uma vida quase interiorana e uma população bastante negra e morena.

E Lima guardaria um recurso semelhante de afastamento e de aproximação diante dessa população que ele definia como "humilde e infeliz" (Barreto, 2012, p.44) e presunçosa:

Quando há vinte anos fui morar nos subúrbios, o trem me irritava. A presunção, o pedantismo, a arrogância e o desdém em que olhavam as minhas roupas desfiadas e verdoengas, sacudiam-me os nervos e davam-me ânimos 
de revolta. Hoje, porém, não me causa senão riso a importância dos magnatas suburbanos. (Barreto, 1921c, p.2)

Essas eram, contudo, distinções frágeis, que se dissipavam quando misturadas nas ruas do Centro: "é no trem que se observa bem a importância dessa gente toda. Eles estão na sua atmosfera própria que os realça desmedidamente. Chegam na Rua do Ouvidor, e desaparecem. São uns fantoches" (ibidem).

Lima não disfarça seu desdém diante "dessa gente", que, confessava ele, o "irritava". Mas, mais importante do que anotar o ressentimento do escritor, é perceber como Lima assume um ar pretensamente distante: "semelhante gente vive de um modo singular".

Enfim, se Lima circulava muito pelo centro, seu bairro, com ou sem restrições, continuava sendo Todos os Santos. Os Barreto moravam na Rua Boa Vista, no topo de uma ladeira, com o vento batendo forte, principalmente de manhã e ao anoitecer. A morada correspondia bem ao estilo local: alpendre central, alguns cômodos para acomodar a família e agregados, cerca ajardinada, quintal ao fundo com banheiro. Era "a casa do louco", como os vizinhos chamavam por causa da alienação que tomara o pai de Lima desde 1902; "Vila Quilombo" como Lima gostava de se referir a ela.

\section{Tempo da sala de visitas ou pobre modernidade}

Essa "gente estranha" protagonizava, ainda, animados saraus, envolvendo a declamação de poemas, muita música e dança (entre choros, maxixes e polcas). Na crônica "Bailes e divertimentos suburbanos", escrita no último ano de vida do escritor, em 1922, Lima descreve uma dessas festas, que costumavam fazer que ficasse insone madrugada adentro. O problema não eram as festas, mas os suburbanos que, na opinião dele, andavam encantados com tudo que era importado. Retomando seu mote do bovarismo, a crítica que o escritor fazia à mania brasileira de gostar de tudo que vem do exterior e é alheio à realidade local, Lima ironizava os costumes da vizinhança. Pior mesmo eram as danças: "polcas adoidadas e violentamente sincopadas", "barcarolas italianas", "tangos, fox-trot, rang-time e um tal de shimmy". Nada de "valsas, mazurcas, quadrilhas ou quadras, etc". Contrariado, Lima reclamava das vogas importadae e, saudosista, do alto de seus $4 \mathrm{l}$ anos, lamenta como o baile já não era mais "carioca e suburbano". Isso sem esquecer-se do descenso na qualidade dos domić́lios dos brasileiros: "Nas salas de visitas das atuais mal cabem o piano e uma meia mobília, adquirida a prestações. Meia dúzia de pessoas, numa delas, estão ameaçadas de morrer asfixiadas com as janelas abertas" (Barreto, 1922, p.2).

Manifestando sempre a falta do que já passou, Lima lamenta o final do tempo da "sala de visitas". E nesse pacote de "artificialidades" brasileiras, lugar destacado teria o futebol. A pretexto de resenhar o livro de Sussekind de Mendonça, O Esporte está deseducando a mocidade brasileira, o escritor se dedica a descrever a licenciosidade das "danças modernas dos subúrbios", acusando de ser o futebol o maior responsável pela proliferação destas "danças desavergo- 
nhadas". "O tal de futebol pôs tanta grosseria no ambiente, tanto desdém pelas coisas de gosto, e reveladoras de cultura, tanta brutalidade de maneiras, de frases e de gestos, que é bem possível não ser ele isento de culpa no recrudescimento geral, no Rio de Janeiro, dessas danças luxuriosas que os hipócritas estadunidenses foram buscar entre os negros e os apaches". E completa Lima "O subúrbio civiliza-se, diria o saudoso Pimentel, que era também suburbano; mas de que forma, santo Deus?".

Lima não só procura se distanciar dos aristocratas dos subúrbios, como também dos novos tempos, da influência dos valores e costumes estrangeiros sobretudo aqueles vindos dos Estados Unidos -, e da entrada das vogas do centro. O resultado seria o fim dos costumes tradicionais, como o violão, o choro e a modinha. Esse seria, inclusive, o mote central do livro Triste fim de Policarpo Quaresma, romance publicado sob a forma de folhetins a partir de 1911. Policarpo era ele próprio um nacionalista e por isso valorizava a tradição dos bailes e serestas, e, em particular, o choro tocado por seu professor Ricardo Coração dos Outros. Já em Clara dos Anjos, como que por contraposição, o nada simpático Cassy usa da sua música para desandar com a vida das moçoilas ingênuas e provincianas dos subúrbios.

Segundo Lima, faltava tudo nos subúrbios - teatrinho de amadores, o pianista dos bailes - e o culpado é também o cinema: "O que havia de característico na vida suburbana, em matéria de diversão, pouco ou quase nada existe mais. $\mathrm{O}$ cinema absorveu todas elas". Além dele, também o carnaval e, como sempre, o futebol: "O futebol flagela também aquelas paragens como faz ao Rio de Janeiro inteiro $[\ldots]$ Nunca lhes vi uma partida, mas sei que as suas regras de bom-tom em nada ficam a dever às dos congêneres dos bairros elegantes”. Nostálgico, ele ajuíza que "o subúrbio não se divertia mais" e, ao contrário "se atordoa e se embriaga não só com o álcool, mas com a lascívia das danças novas que o esnobismo foi buscar no arsenal da hipocrisia norte-americana" (Barreto, 1922).

\section{Os subúrbios: personagem central dos romances}

E foi tendo esse ambiente como inspiração que o escritor construiu boa parte de sua literatura. Uma das primeiras visitas de Isaías Caminha, mal chegado ao Rio de Janeiro, foi o "passeio de pragmática" a Botafogo, não tendo gostado do que viu. Os bairros suburbanos é que lhe agradavam, e ele recorda que passeava de bonde e a pé, sem destino certo, "passando de um bairro para outro, procurando travessas despovoadas e sem calçamento..." (Barreto, 2010b, p.150).

Já seu personagem Gonzaga de Sá recorda a fisionomia "ainda fresca", porém irracional, do subúrbio carioca nos começos desse século. O relato é comovente:

O arruamento do subúrbio é delirante. Uma rua começa larga, ampla, reta; vamos-lhe seguindo o alinhamento, satisfeitos, a imaginar os grandes palácios que a bordarão daqui a anos, de repente, estrangula-se, bifurca-se, 
subdivide-se num feixe de travessas, que se vão perder em muitas outras que se multiplicam e oferecem os mais transtornados aspectos. Há o capinzal, o arremedo de pomar, alguns canteiros de horta; há a casinha acaçapada, saudosa da toca troglodita; há a velha casa senhorial de fazenda com as suas colunas heterodoxas; há as novas edificações burguesas, com ornatos de gesso, cimalha e campoteira, varanda ao lado e gradil de ferro em roda. Tudo isso se embaralha, confunde-se, mistura-se e bem não se colhe logo como a população vai-se irradiando da via férrea. As épocas se misturam; os anos não são marcados pelas coisas mais duradouras e perceptíveis. (Barreto, 1990, p.190)

Em Policarpo Quaresma ele volta à descrição topográfica do mundo suburbano, acrescentando-lhe o elemento humano que o povoa:

Há pelas ruas damas elegantes, com sedas e brocados, evitando a custo que a lama ou o pó lhes empanem o brilho do vestido; há operários de tamanco; há peralvilhos à última moda; há mulheres de chita; e assim pela tarde quando essa gente volta do trabalho ou do passeio, a mescla se faz numa mesma rua, num quarteirão, e quase o mais bem posto não é que entra na melhor casa. (Barreto, 2011, p.190)

Se a impressão é de mistura, de tempos e de população, Lima não perde de vista a desigualdade social por lá existente e o fato de boa parte da população ainda morar em condições deploráveis: "Casas que mal dariam para uma pequena família, são divididas, subdivididas, e os minúsculos aposentos assim obtidos, alugados à população miserável da cidade". As "profissões mais tristes e mais inopinadas", conta ainda ele, são exercidas pelos habitantes desses "caixotins humanos":

Além dos serventes de repartições, contínuos de escritórios, podemos ver velhas fabricantes de rendas de bilros, compradores de garrafas vazias, castradores de gatos, cães e galos, mandingueiros, catadores de ervas medicinais, enfim, uma variedade de profissões miseráveis que as nossas pequenas e grande burguesias não podem adivinhar. (ibidem, p.192)

O retrato é tudo menos óbvio, com a região perfilando uma população muito diversa em termos de acesso econômico e social.

É uma alta sociedade muito especial e que só é alta nos subúrbios. Compõe-se em geral de funcionários públicos, de pequenos negociantes, de médicos com alguma clínica, de tenentes de diferentes milícias, nata essa que impa pelas ruas esburacadas daquelas distantes regiões, assim como nas festas e nos bailes, com mais força do que a burguesia de Petrópolis e Botafogo. (ibidem)

Quase como um retrato na parede, Lima descreve um dia de domingo: A tarde se aproximava e as toilettes domingueiras já apareciam nas janelas. Pretos com roupas claras e grandes charutos, grupos de caixeiros com flores estardalhantes; meninas em cassas bem engomadas; cartolas antediluvianas ao lado de vestidos pesados de cetim negro, envergados em corpos fartos 
de matronas sedentárias; e o pobre domingo aparecia assim decorado com a simplicidade dos humildes, com a riqueza dos pobres e a ostentação dos tolos. (ibidem)

O limite para a identificação com os subúrbios é tênue, e não poucas vezes o autor prefere vestir sua "roupa" de estrangeiro na região; daquele que não entende determinadas atitudes e gosta mas estranha o ambiente.

É esse o tom da descrição da arquitetura local. Chalés, ladrilhos, puxadinhos, alpendres, casas de cômodo, azulejos, portais de ferro, enfim, uma grande e caótica mistura de materiais e arquiteturas faziam as graças e as desgraças desses subúrbios de Lima. Talvez por isso a primeira frase de Clara dos Anjos - seu romance mais suburbano - seja também a mais definitiva: “O subúrbio é o refúgio dos infelizes". A protagonista dessa narrativa é uma “morena de seios empinados"; moça romântica que vivia por esperar seu príncipe encantado que chegaria sob a forma de Cassi, um modinheiro branco que vivia no Meier.

A residência dos pais de Cassi ficava num subúrbio tido como elegante, porque lá também há estas distinções. Certas estações (de trem) são assim consideradas e certas partes de determinadas estações gozam, às vezes, dessa consideração [...] Nos subúrbios há disso... Essa estranha gente. (Barreto, 2012, p.98)

Ora, "essa estranha gente" eram seus vizinhos de porta, a colegas de boteco e de estação que, vez por outra, Lima convertia em “desconhecidos”. Será preciso, porém, conceder e concluir que os subúrbios não eram, mesmo, regiões homogêneas. Se na contraposição com o centro pareciam muito semelhantes entre si, olhados de dentro e de perto deixavam perceber muitas diferenciações internas.

No conto, "O número da sepultura", ${ }^{8}$ Lima volta ao tema dos "subúrbios estranhos", quando descreve a Travessa das Saudades como "uma pitoresca rua, afastada alguma coisa das linhas da Central, cheia de altos e baixos, dotada de uma caprichosa desigualdade de nível, tanto no sentido longitudinal como no transversal". O que o escritor mostra de maneira sensível é um processo histórico de parcelamento das terras para a construção de lotes residenciais, quando os subúrbios seriam ocupados por segmentos tidos como mais "populares". Esse foi um movimento que começou a atingir intensamente o que hoje são os bairros de São Cristóvão, Tijuca, Vila Isabel, Piedade desde a década de 1870. A partir de 1890 ele incidiria sobre Méier, Madureira e Engenho Novo e Inhaúma. Começou então um surto descontrolado de abertura de ruas e loteamentos. Ruas mal traçadas, abertas em terrenos acidentados, sem meios-fios, iam surgindo por todos os lados, assim como construções novas e feitas em lotes inadequados e desprovidos de alinhamentos (Reis, 1977, p.53).

São essas vias desiguais que Lima observa no conto "O moleque”, onde os subúrbios surgem como pano de fundo: "É um subúrbio de gente pobre, e o bonde que lá leva atravessa umas ruas de largura desigual, que, não se sabe 
por que, ora são muito estreitas, ora muito largas, bordadas de casas e casitas sem que nelas se depare um jardinzinho mais tratado ou se lobrigue, aos fundos, uma horta mais viçosa". O local ficaria pintado, por Lima Barreto, por uma população que, para além de adotar costumes que lhes são distantes, "fogem para lá, sobretudo para seus morros e escuros arredores, aqueles que ainda querem cultivar a Divindade como seus avós”. Na visão eternecida de Lima

[...] nas suas redondezas, é o lugar das macumbas, das práticas de feitiçaria com que a teologia da polícia implica, pois não pode admitir nas nossas almas depósitos de crenças ancestrais. O espiritismo se mistura a eles e a sua difusão é pasmosa. A Igreja católica não satisfaz o nosso povo humilde. [...] O padre, para o grosso do povo, não se comunica no mal com ela; mas o médium, o feiticeiro, o macumbeiro, se não a recebem nos seus transes, recebem, entretanto, almas e espíritos que, por já não serem mais da terra, estão mais perto de Deus e participam um pouco da sua eterna e imensa sabedoria. (Barreto, 2010a, p.196)

Lima se emociona com essa mistura de religiões:

[...] o curioso é o amálgama de tantas crenças desencontradas a que preside a Igreja católica com os seus santos e beatos. A feitiçaria, o espiritismo, a cartomancia e a hagiologia católica se baralham naquelas práticas, de modo que faz parecer que de tal baralhamento de sentimentos religiosos possa vir nascer uma grande religião, como nasceram de semelhantes misturas as maiores religiões históricas. $\mathrm{Na}$ confusão do seu pensamento religioso, nas necessidades presentes de sua pobreza, nos seus embates morais e dos familiares, cada uma dessas crenças atende a uma solicitação de cada uma daquelas almas, e a cada instante de suas necessidades. (ibidem, p.196)

Esse universo extenso, e que escapa às falácias da nossa modernidade, é que Lima vai construíndo com sua literatura. Alí está a descrição da cidade e de seus subúrbios. Alí está também um escritor que se inventa junto com seus protagonistas. Ele é cada uma de suas figuras e nenhuma delas ao mesmo tempo. É o subúrbio, mas também não faz parte dele.

Região e espaço são marcas fundamentais dessa obra literária. Não há subúrbio sem centro e é essa linha, real e simbólica, que Lima percorre de maneira literal e metafórica a cada dia. É ele, no fundo, a personagem principal que perambula entre o subúrbio e o centro da então capital do país, e vice-versa, demarcando, ainda mais, uma fronteira própria, refeita a partir da linha de ferro, tantas vezes imaginada, da Central. Seguindo sua própria definição, em "O destino da literatura", Lima Barreto é mesmo "um sujeito sociável” e que "passa, das vinte quatro horas do dia, mais de quatorze na rua, conversando com pessoas de todas as condições e classes" (Barreto, 1921b).

Os subúrbios são, porém, uma sombra onipresente; afetiva, mas da qual ele também gostaria de se livrar. Talvez por esse motivo o antropólogo M. Taussyg (1993, p.129) tenha chamado de mimeses, a essa perspectiva própria da literatura, capaz de registrar "sameness and difference, of being like, and of beeing 
other". Essa maneira de parecer descrever o contexto, mas também trapacear com ele.

A literatura permite, pois, a abertura desse espaço "entre" de proximidade e de distância; que põe em contato, mas também aparta. Por isso, esses muitos textos de Lima Barreto sobre os subúrbios são um pouco de tudo ao mesmo tempo: generosos e irônicos; de olho no passado e voltados para o presente; melancólicos e projetivos. Aí residem seus próprios fantasmas, as suas próprias contradições (Bhaba, 1998; Santiago, 2007).

Notas

1 Este artigo é uma versão condensada e, portanto, fortemente pautada pelo livro que acabo de publicar e que se chama Lima Barreto triste visionário (Cia. das Letras, 2017).

2 Fontes: Diretoria Geral de Polícia Administrativa, Arquivo e Estatística. Recenseamento do Rio de Janeiro (Districto Federal): Realizado em 20 de setembro de 1906. Rio de Janeiro: Oficina de Estatística, 1907, p.XL.

3 Esse trecho é pautado pelo belo artigo de Nicolau Sevcenko de 30 de setembro de 2007. Disponível em: <http://wwwl.folha.uol.com.br/fsp/mais/fs3009200701.htm>.

4 Essa cresceu no mesmo período de 811.443 para 1.157 .873 habitantes.

5 A Estrada de Ferro Central teve as seguintes denominações ao longo do tempo: E. F. Dom Pedro II (1858-1889); E. F. Central do Brasil (1889-1975). Passou depois a se chamar R.F.F.S.A. (1975-1984), posteriormente à CBTU (1984-1994) e FlumiTrens (1994-1998), até ser privatizada, em 1998.

6 Em 1925, um decreto de Arthur Bernardes homenageando o centenário de nascimento do antigo Imperador renomeia a estação como "Dom Pedro II".

7 Não encontramos mais informações sobre a desativação da estação. Fontes indicam que seu desligamento ocorreu no final dos anos 1960, talvez devido ao movimento reduzido de passageiros.

8 Texto conferido a partir de Revista Souza Cruz. Rio de Janeiro, março de 1921. Ano VI, n. 51 .

\section{Referências}

ABREU, M. de A. A evoluação urbana no Rio de Janeiro. Rio de Janeiro: Iplanrio; Jorge Zahar, 1987.

BARRETO, L. Os outros. Careta, Rio de Janeiro, 11 dez.1915. . A estação. Gazeta de Notícias, Rio de Janeiro, 6 out. 1921a, p.2. . O destino da literatura. Revista Souza Cruz, n.58-59, out./nov. 1921 b. . O trem de subúrbio. Gazeta de Notícias, Rio de Janeiro, 21 dez. 1921c, p.2. . O trem dos subúrbios. Gazeta de Notícias, Rio de Janeiro, 21 dez. 1921 d. - Vida e morte de M. J. Gonzaga de Sá. Rio de Janeiro: Garnier, 1990. 
BARRETO, L. Bailes e diverimentos suburbanos. Gazeta de Notícias, Rio de Janeiro, 7 fev. 1922, p.2.

O moleque. In: SCHWARCZ, L. M. (Org.) Contos completos de Lima Barreto. São Paulo: Cia. das Letras, 2010a. p.141-51.

Recordações do escrivão Isaias Caminha, São Paulo: Cia. das Letras, 2010 b.

. Triste fim de Policarpo Quaresma. São Paulo: Penguin \& Cia. das Letras, 2011.

Clara do Anjos. São Paulo: Cia. das Letras, 2012.

BENJAMIN, W. Paris, capitale du XIX siècle: Le livre des passages. Paris: Cerf, 1997.

BHABA, H. O lugar da cultura, Belo Horizonte: Ed. da UFMG. 1998.

FIGUEIRA, M. F. Memória histórica da Estrada de Ferro Central do Brasil. Rio de Janeiro: Imprensa Nacional, 1908.

MACHADO DE ASSIS, J. M. Dom Casmurro. São Paulo: Penguin; Cia. das Letras, 2016.

REIS, J. de O. O Rio de Janeiro e seus prefeitos: evolução urbanística da cidade. Rio de Janeiro: Prefeitura do Rio de Janeiro, 1977.

RESENDE, B. Lima Barreto e o Rio de Janeiro em fragmentos. Belo Horizonte: Autêntica Editora, 2016.

SANTIAGO, S. A vida como literatura. Belo Horizonte: Ed. da UFMG, 2007.

SANTOS, N. As freguesias do Rio antigo vistas por Noronba Santos, Rio de Janeiro: O Cruzeiro, 1965, p.36.

Meios de Transporte no Rio de Janeiro: história e legislação. Rio de Janeiro:

Dep. Geral de Documentação e Informação Cultura, 1996 (reedição).

SARLO, B. Jorge Luis Borges, um escritor na periferia. São Paulo: Iluminuras, 2008.

SCHWARCZ, L. M. Lima Barreto triste visionário. São Paulo: Cia. das Letras, 2017.

SILVA, M. L. P. da. A favela e o subúrbio: associações e dissociações na expansão suburbana da favela. In: OLIVEIRA, M. P. de O.; FERNANDES, N. da N. (Org.) 150 anos de subúrbio carioca. Rio de Janeiro: Lamparina; Faperj; EdUFF, 2010.

TAUSSIG, M. Mimesis and alterity: a particular history of the senses. New York: Routledge, 1993.

VASCONCELOS. M. de. Vias Brasileiras de Comunicação: Estrada de Ferro Central do Brasil. 6.ed. Rio de Janeiro: Conselho Nacional de Geografia, 1947.

RESUMO - O objetivo deste artigo é descrever os subúrbios e a antiga capital do Brasil, Rio de Janeiro, no começo do século XX e durante a Reforma Pereira Passos. Nosso protagonista e guia é, nesse caso, o escritor Lima Barreto, uma voz importante e única nesse contexto do pós abolição.

PALAVRAS-CHAVE: Lima Barreto, Reforma Pereira Passos, Subúrbios, Centro.

ABSTRACT - The main goal of this article is to describe the suburbs and the old capital of Brazil, Rio de Janeiro, in the beginning of the $20^{\text {th }}$ century, during the Pereira Passos 
Reform. Our protagonist and guide, in this case, is the writer Lima Barreto, an important and unique voice in the post-abolition milieu.

KEYWORDS: Lima Barreto, Pereira Passos Reform, Suburbs, City center.

Lilia Moritz Schwarcz é professora titular no Departamento de Antropologia da USP. Foi visiting professor em Oxford, Leiden, Brown, Columbia e Princeton, onde é global professor desde 2010. É autora, entre outros, de Retrato em branco e negro (1987), O espetáculo das raças (1993), As barbas do Imperador (1998), A longa viagem da biblioteca dos reis (2002), O sol do Brasil (2008). Foi curadora de uma série de exposições e desde 2015 e atua como curadora adjunta do Masp desde 2015.

@ - lili.schwarcz@gmail.com

Recebido em 25.9.2017 e aceito em 11.10.2017.

I Departamento de Antropologia, Faculdade de Filosofia, Letras e Ciências Humanas, Universidade de São Paulo, São Paulo, São Paulo, Brasil. 